\title{
Deterjan çözeltilerinin tarım topraklarının bazı özellikleri üzerine etkileri
}

\section{Effects of detergent solution on some soil properties of cultiveted soils}

\author{
Serdar BiLEN ${ }^{1}$, Leyla Okyay KAYA ${ }^{2}$ \\ ${ }^{1}$ Atatürk Üniversitesi, Ziraat Fakültesi, Toprak Bilimi ve Bitki Besleme Bölümü, Erzurum, Türkiye \\ ${ }^{2}$ Atatürk Üniversitesi, Fen Bilimleri Enstitüsü, Toprak Bilimi ve Bitki Besleme Anabilim Dalı, Erzurum, Türkiye
}

\section{Eser Bilgisi / Article Info}

Araştırma makalesi / Research article

DOI: 10.17474/artvinofd.382295

Sorumlu yazar / Corresponding author

Serdar BiLEN

e-mail: sbilen@atauni.edu.tr

ORCID: 0000-0003-0516-1893

\section{Geliş tarihi / Received}

22.01.2018

Düzeltme tarihi / Received in revised form

22.03.2018

Elektronik erişim / Online available

18.04.2018

Anahtar kelimeler:

Deterjan çözeltileri

İnkübasyon

Toprak solunumu

Bakteri popülasyonu

Mantar popülasyonu

Keywords:

Detergent solutions

Incubation

Soil respiration

Bacteria population

Fungus population

\begin{abstract}
Özet
Bu çalışmada 6 farklı deterjan $\left(D_{1}, D_{2}, D_{3}, D_{4}, D_{5}\right.$ ve $\left.D_{6}\right)$ çözelti konsantrasyonlarının topraklara sulama suyu olarak 30, 60 ve 90 günlük periyotlarda uygulanması sonucu toprakların fiziksel, kimyasal ve biyolojik özelliklerindeki değişimler araştırılmıştır. Deneme serada yürütülmüş ve deneme süresi boyunca toprakların su içerikleri tarla kapasitesi seviyesinde sabit tutulmuştur. Araştırma sonuçlarına göre; farklı toz deterjanlarının konsantre (Kkon) çözeltileri inkübasyon sürelerinin artışına bağlı olarak toprakların ortalama reaksiyon $(\mathrm{pH})$ değerleri, değişebilir $\mathrm{Na}$, toplam $\mathrm{N}$ ve elverişli $\mathrm{P}$ ve $\mathrm{B}$ içeriklerinde artışa sebep olmuştur. Toprakların $\mathrm{CO}_{2}$ solunumu, bakteri ve mantar sayıları ise inkübasyon sürelerinin artışına bağlı olarak azalma göstermiștir. Toprakların $\mathrm{CO}_{2}$ solunumu ve bakteri ve mantar sayılarında azalmalar ile değişebilir $\mathrm{Na}$, toplam $\mathrm{N}$ ve elverişli $\mathrm{P}$ ve $\mathrm{B}$ içeriklerindeki artışlar hafif bünyeli topraklarda daha yüksek oranda gerçekleşmiştir.
\end{abstract}

\section{Abstract}

In this study, the changes in chemical and biological properties of the soil applicated 6 different detergents $\left(D_{1}, D_{2}, D_{3}, D_{4}, D_{5}\right.$ and $\left.D_{6}\right)$ concentrations (Kkon) as irrigation water in 30,60 and 90 days were investigated at the end of the incubation days. The humidity levels of the soil have been kept constant at the moisture level of the soil throughout the experiment period in greenhouse conditions. Soil $\mathrm{pH}$, exchangeable $\mathrm{Na}$, total $\mathrm{N}$ and the available $\mathrm{P}$ and $\mathrm{B}$ contents of the soil increased as the incubation times of the concentrate $\left(\mathrm{K}_{\mathrm{KON}}\right)$ detergent solutions of 6 different powder detergents increased. $\mathrm{CO}_{2}$ respiration of soil, bacterial and fungal counts decreased. Decreases in $\mathrm{CO}_{2}$ respiratory, bacterial and fungal numbers of soils and increased $\mathrm{Na}$, total $\mathrm{N}$ and favourable $\mathrm{P}$ and $\mathrm{B}$ contents were higher in light soil.

\section{Giriş}

Toprağın fiziksel, kimyasal ve biyolojik özelliklerinin insan müdahalesi sebebiyle bozulması toprak kirliliği, olarak tanımlanabilir. Gelişme ile paralel olarak ortaya çıkan endüstriyelleşme bazı bilinçsiz sanayi kuruluşlarının ortaya çıkmasına ve atıklarını doğaya bırakmasına sebep olabilmektedir. Doğaya bilinçsizce bırakılan bu atıklar toprakta yaşayan organizmalara doğrudan veya dolaylı ciddi zararlar vermektedir. Dünya üzerinde bulunan topraklar birbirinden farklı oranlarda kirletilmesine karşın, en fazla risk toprakta yaşayan canlılar üzerine olmaktadır.

\section{Dünya Savaşı sırasında Avrupa ve Amerika`da kullanılan} sentetik temizleyiciler bulaşıcı hastalıkların önlenmesinde ve temizlik işlerinde büyük kolaylıklar sağlamıştır. Ancak bu maddelerin rastgele üretilmesi ve çevreye yayılmasıyla 1960\% yıllarda A.B.D gibi bazı batı ülkelerinde deterjanların doğa kirlenmesine katkısı olduğu belirlenmiş ve bu konuda bir dizi önlemler alma zorunluluğu ortaya çıkmıştır (Pasinli 2009).

Tipik bir deterjan, bir surfaktan, yapıcı (zeolit, sodyum tripolifosfatlar), ilişkili bir polikarboksilat veya yapıcı katkı maddesi ve bir ağartma maddesinden (perkarbonat veya perborat) oluşur (Pettersson ve ark. 2000; Carson ve ark. 2006). Ayrıca deterjanlarda renk vericiler, alkalin kontrol maddeleri, oksijen ağartıcıları, ani kontrol maddeleri, 
korozyon önleyicileri, yeniden çökelme önleyici maddeler, parfümler, ağartma maddeleri için (tetraasetiletilendiamin veya TAED) aktivatörleri ve enzimler (proteazlar, lipazlar ve diğerleri) (Malmos 1990; Pettersson ve ark. 2000; Carson ve ark. 2006; Bajpai ve Tyagi 2007; Yangxin ve ark. 2008) gibi katkı maddeler içermektedirler. Deterjan çözeltilerinde bulunan bazı maddeler çevresel faktörler altında farklı oranlarda biyolojik olarak parçalanabilirler (Pickup 1990; Kolber 1990; Petterson ve ark. 2000).

Topraklara deterjan atıklarının uygulanmasının en önemli sonuçlarından birisi toprak tuzluluğunun artmasıdır. Deterjan çözeltilerinin topraklara etkileri; sulama suyu kalitesi, sulama hızı, yeraltı suyu derinliği, drenaj, toprak geçirgenliği ve organik madde içeriği gibi birtakım faktörler tarafından etkilenmektedir (DSÖ 2006).

Yüksek oranda fosfor ihtiva eden deterjan atıkları atık su sistemlerine geçmekte ve çevre için olumsuz etkiler oluşturmaktadır. Avusturalya'da atıksu sistemlerine aktarılan fosforun yüzde $30^{\prime} u$, fosfatın da yüzde 20 'si deterjan kaynaklıdır. Bugün kullanılan temizlik ürünlerinin çevreye zararı $\% 80$ civarındayken, organik temizlik maddelerinde bu oran \%20 seviyelerine kadar düşürülmüştür (Anonim 2012).

Toz deterjanların temel maddelerinden birisi olan sodyum polifosfatlar atık sularda yoğun olarak bulundukları zaman ortamda bulunması muhtemel azot bileşiklerinin de yardımı ile gübre etkisi göstermektedir. Bunun sonucunda göllerde ve akıntısı olmayan deniz sularında bitkisel hayatı olumsuz yönde etkileyecek alg ve yosunların büyük boyutlarda artmasına sebep olmaktadır (Pasinli 2009). Deterjanlardaki fosfatlar, dünyanın birçok yerinde suların ötrofikasyonuna sebep olmaktadırlar (Schindler 1974; Lee ve ark. 1978; Smith ve ark. 1999). Sularda önemli sınırlayıcı besin maddesi olan aşırı fosfatlar bakteri ve alg gelişimini teşvik edebilirler ve balık ölümüne neden olabilirler (Schindler 1974; Smith ve ark. 1999; Yangxin ve ark. 2008). Fosfatlar, yosunlar için gübre yerine geçerek, aşırı çoğalmalarına sebep olmaktadırlar. $\mathrm{Bu}$ yosunları parçalayan bakteriler sudaki oksijeni tüketerek ötrofikasyona sebep olmaktadırlar (Mercola 2012).
Son zamanlarda fosfatsız deterjanların da üretilmeye başlaması ve bazı ülkelerde deterjanlarda kullanılan fosfatın yasaklanması ile fosfat içermeyen deterjan kullanılan bölgelerde su kalitesi anlamlı derecede yükselmiştir (Erbay 2010; Dökmeci 2012).

Sabunlarda ve deterjanlarda bulunan sodyum perborat çözeltideki B kaynağını oluşturmaktadırlar (Gross ve ark. 2005). Genel olarak B biyolojik bozulmaya (Fox ve ark. 2002) uğramadığı için deterjanlardaki bor kullanımı bir takım çevresel sorunlara neden olması sebebi ile bazı ülkelerde sınırlı kullanımı mevcuttur (Gross ve ark. 2005).

Ülkemizde üretilen deterjanlara katılan dedosil benzen (DDB) yüzey-aktif maddeler su ve toprakta bakteri ve enzimlerin etkisiyle oldukça güç çözünmekte dolayısıyla doğada zamana bağlı olarak artan oranda birikmektedirler (Pasinli 2009).

Deterjan atıklarının suya ve tarım topraklarına kontrolsüz olarak boşaltılması biyolojik ekosistemlerin zarar görmesine sebep olmaktadırlar Toprak mikroorganizmaları, biyolojik bir toprak bileşeni olarak, deterjan atıklarının biyolojik bozunumlarını bir dereceye kadar sağlayarak onları daha az zehirli veya enerji bakımından önemli besleyici element kaynakları haline getirebilirler (Stojanovic ve ark. 1990). Temel olarak, deterjan konsantrasyonlarının artması veya toprakta birikmesi (Goncaruka ve Sidorenko 1986), mikroorganizmaların sayısının hızlı bir şekilde azalmasına sebep olmaktadır. Yapılan bir çalışmada; yüksek deterjan konsantrasyonlarına bazı oligonitrofili bakterileri ve mikroorganizmaların en dirençli grubu olan toprak mantarları daha az zarar gördüğü ve mikroorganizma grupları üzerinde en düşük toksik etkinin, en düşük deterjan konsantrasyonunda (\%0.001) gözlendiği, buna karşın \%0.1-1 konsantrasyonda mikroorganizma büyümesini büyük oranda inhibe ettiği ifade edilmektedir (Mandic ve Djukic 2006).

Yapılan çalışmada deterjan atıklarının toprağa uygulamasından sonra toprak $\mathrm{pH}$ değerinin arttığı ifade edilmektedir (Pinto ve ark. 2010; Al-Hamaiedeh ve Bino 2010). Çamaşır deterjanlarının yüksek alkalin özellik göstermesi deterjan çözeltilerinin pH'sının (pH 8 ila 10) 
yükselmesine sebep olduğu bilinmektedir (ChristovaBoal ve ark. 1996; Eriksson ve ark. 2002).

Bu çalışma; piyasada yaygın olarak kullanılan deterjanların ve bunların yıkama suyu atıklarının tarım topraklarının bazı kimyasal, fiziksel ve biyolojik özellikleri üzerine etkilerini ortaya koymak için yapılmıştır.

\section{MATERYAL ve YÖNTEM}

\section{Materyal}

Denemede materyal olarak farklı bünyede 2 farklı toprak örneği ve 6 farklı deterjan kullanıımıştır.

\section{Toprak örneklerinin alındığı bölge}

$\mathrm{Bu}$ araştırmada, Atatürk Üniversitesi Ziraat Fakültesi Tarımsal Araştırma ve Yayım Müdürlüğü 4 No'lu deneme sahasından alınan Orta Bünyeli ve Daphan Ovası İspir Yolu Serisinden alınan Ağır Bünyeli toprak örnekleri kullanılmıştır.

\section{Toz deterjan}

Bu çalışmada kullanılan deterjanların içerikleri;

Deterjan 1: \%5-15 oranında anyonik yüzey aktif madde, oksijen bazlı ağartıcı, < \%5 oranında non-iyonik aktif madde, fosfonat, polikarboksilat, sabun, zeolit ve kısmen de enzim, optik parlatıcı ve parfüm içermektedir.

Deterjan 2: $<\% 5$ oranında poliakriat, $<\% 5$ oranında noniyonik aktif madde, $<\% 5$ oranında sabun, $\% 5-15$ oranında anyonik aktif madde, \%5-15 oranında oksijen bazlı ağartıcı ve kısmen de enzim, optik, benzil alkol, butilfenil metilpropionat ve linalool içermektedir.

Deterjan 3: \%5-15 oranında anyonik yüzey aktif madde ve oksijen bazlı ağartıcı, <\%5 oranında non-iyonik aktif madde, fosfonat, polikarboksilat, zeolit ve kısmen de enzim, optik parlatıcı, parfüm ve butilfenil metilpropionat içermektedir.

Deterjan 4: $\leq \% 5$ oranında sabun, noniyonik aktif, polikarboksilat, fosfonat, zeolit, \%5-15 oranında ve \%1530 oranında anyonik aktif ve oksijen bazlı ağartıcı, enzim, optik parlatıcı, parfüm, butilfenil metilpropionat, sitronellat ve hexil sinnamat içermektedir.
Deterjan 5: anyonik aktif madde, \%5-15 oranında, noniyonik aktif madde ve sabun $<\% 5$ oranında, fosfat \%5-15 oranında ve parfüm içermektedir.

Deterjan 6: >\%30 oranında Na-borat (Boraks), \%15-20 oranında sodyum sterat (sabun) ve $\leq \% 5$ oranında Soda içermektedir.

\section{Yöntem}

\section{Toprak örneklerinin analize hazırlanması ve analiz yöntemleri}

Denemede kullanılan toprak örnekleri laboratuarda hava kuru duruma getirildikten sonra $4 \mathrm{~mm}$ 'lik elekten elenerek saksılara konulmuştur. iki $\mathrm{mm}^{\prime}$ lik elekten geçirilen toprak örnekleri üzerinde kimyasal, fiziksel ve biyolojik analizler yapılmıştır.

Deneme topraklarının toprak reaksiyonu Beckman $\mathrm{pH}$ metresi ile (Handershot ve ark., 1993), kireç miktarı Scheibler Kalsimetresi ile (Goh ve ark., 1993), organik madde Smith-Weldon yöntemi ile (Tiessen ve Moir 1993), katyon değişim kapasitesi (KDK) atomik absorbsiyon spektrofotometresi ile (Rhoades, 1982), değişebilir katyonlar ( $\mathrm{Ca}, \mathrm{Mg}, \mathrm{Na}$ ve $\mathrm{K}$ ) alev fotometresinde ile (Knudsen ve ark., 1982), elverişli fosfor molibdofosforik mavi renk yöntemine göre spektrofotometre ile (Olsen ve Sommers 1982), toplam azot Kjeldahl yöntemi ile (Mc Gill ve Figueiredo 1993), elektrik iletkenlik elektriki kondüktivite aleti ile (Demiralay, 1993), toprak tekstürü Bouyoucos Hidrometre yöntemi ile (Gee ve Bauder, 1986), ekstrakte edilebilir $\mathrm{Fe}, \mathrm{Cu}, \mathrm{Zn}$ ve $\mathrm{Mn}$ içerikleri DTPA (dietilentriamin pentaasetikasit) yöntemi ile ICP OES spektofotometresinde (Inductively Couple Plasma Spectrophotometer) (Perkin-Elmer, Optima 2100 DV, ICP/OES) direk olarak okunarak (Mertens 2005) belirlenmiştir.

\section{Toprak materyalindeki bakteri ve mantar sayısının tespiti}

Toprak materyalindeki bakteri ve mantar sayımı dilüsyon metoduna göre $10^{-5}$ dilisyon oranında yapılmıştır. Bakteri sayımı Nutrient Agar (NA), mantar sayımı Potato Dextrose Agar (PDA) besiyeri üzerinde, $28^{\circ} \mathrm{C}^{\prime}$ de 48 saat süre ile gelişen bakterilerde koloni sayımı ve mantarlarda spor sayımı yapılmıştır (Germida 1993; Kızıloğlu ve Bilen 1997). 
Toprakların $\mathrm{CO}_{2}$ miktarının tespiti (bazal respirasyon) Toprak örneğinden açığa çıkan $\mathrm{CO}_{2}$ gazının 20 gün süre ile $25 \pm 1^{\circ} \mathrm{C}$ karanlıkta $\mathrm{NaOH}$ içerisinde inkübasyona bırakılmış, inkübasyon sonunda ortama $\mathrm{BaCl}$ ilave edilmiş ve $\mathrm{BaCO}_{3}{ }^{\prime}$ In çökertilerek çözelti $\mathrm{HCl}$ ile titre edilmiştir. Titrasyon sonucu elde edilen değerden BR Oranı $(\mathrm{mg} \mathrm{CO} 2$ $\mathrm{kg}$ toprak $\left.^{-1}\right)=\left(\mathrm{CO}_{2}\right.$ toprak $-\mathrm{CO}_{2}$ air $) / 20$ gün formül yardımı ile toprağın $\mathrm{C}$ ve $\mathrm{CO}_{2}$ miktarı belirlenmiştir (Islam ve Weil, 2000).

\section{Deterjan çözeltilerinin hazırlanması ve denemenin yürütülmesi}

Araştırmada 6 farklı toz deterjan kullanılarak konsantre stok deterjan çözeltileri $\left(\mathrm{K}_{\mathrm{kon}}\right)$ hazırlanmıştır. Denemede kullanılacak konsantre deterjan çözeltileri $\left(\mathrm{K}_{\mathrm{kon}}\right)$; her bir deterjanın ambalaj paketleri üzerinde belirtilen kullanma talimatına göre orta kirli çamaşırlar için önerilen miktarlarda deterjan kullanılarak ve ön yıkamasız olarak ilgili yıkama sıcaklığında deterjan çözeltileri hazırlanmış ve plastik depolarda muhafaza edilmişlerdir.

Saksı topraklarına bir kontrol $\left(D_{0}\right)$ ve 6 farklı deterjan $\left(D_{1}\right.$, $D_{2}, D_{3}, D_{4}, D_{5}$ ve $\left.D_{6}\right)$ 'dan hazırlanan konsantre $\left(K_{\text {kon }}\right)$ deterjan çözeltileri saksı topraklarına sulama suyu olarak uygulanmıştır. Sulamanın yapııdığı tarihten itibaren 30, 60 ve 90 günlük periyotların sonunda toprakların fiziksel, kimyasal ve biyolojik analizleri yapılarak kontrol toprağı ile karşılaştırılmıştır.

Deneme süresince toprakların nem düzeyleri tarla kapasitesi nem değerinde sabit tutulmuş, toprakların yarayışlı nem kapasitesinin \%60 nem miktarı ağırlık esasına göre topraktan uzaklaştığında sulama suyu olarak deterjan çözeltileri ilave edilmiş ve toprak nem içeriği tarla kapasitesinde sabit tutulmuştur.

\section{Deneme planı}

Saksı topraklarına bir kontrol $\left(D_{0}\right)$ ve 6 farklı deterjan $\left(D_{1}\right.$, $D_{2}, D_{3}, D_{4}, D_{5}$ ve $\left.D_{6}\right)$ 'dan hazırlanan konsantre $\left(K_{\text {kon }}\right)$ deterjan çözeltileri saksı topraklarına 3 tekerrürlü olarak uygulanmış ve toplam 126 saksıda yürütülmüştür.

\section{İstatistiksel analiz yöntemleri}

Denemeden elde edilen analiz sonuçları, SPSS 17 istatistik programı kullanılarak ortalamalar arasındaki farkları belirlemek için ANOVA (varyans) analizine tabi tutulmuşlardır (Yıldız ve Bircan 1991)

\section{BULGULAR VE TARTIŞMA}

\section{Deneme Alanı Topraklarının Bazı Fiziksel ve Kimyasal Özellikleri}

Deneme alanının bazı fiziksel ve kimyasal özelliklerini ortaya koymak amacı ile deneme alanını temsil edecek şekilde 0-20 cm derinliğinden alınan toprak örnekleri üzerinde rutin toprak analizleri yapılmış ve analiz sonuçları Çizelge 1'de verilmiştir.

Çizelge 1. Deneme alanı topraklarının bazı fiziksel, kimyasal ve biyolojik özellikleri

\begin{tabular}{|c|c|c|c|}
\hline \multicolumn{2}{|l|}{ Özellik } & $\begin{array}{l}\text { Çiftlik } \\
\text { Toprağı }\end{array}$ & $\begin{array}{l}\text { Daphan } \\
\text { Toprağı }\end{array}$ \\
\hline \multicolumn{2}{|l|}{$\mathrm{pH}(1: 2.5)$} & 7.19 & 7.47 \\
\hline \multicolumn{2}{|l|}{ Organik madde (\%) } & 1.92 & 2.47 \\
\hline \multicolumn{2}{|c|}{ Kireç, $\mathrm{CaCO}_{3}(\%)$} & 0.558 & 0.671 \\
\hline \multicolumn{2}{|c|}{ Elektriksel iletkenlik (EC) $\left(\mu \mathrm{S} \mathrm{cm}^{-1}\right)$} & 109 & 99 \\
\hline \multicolumn{2}{|c|}{ Toplam N (\%) } & 0.19 & 0.12 \\
\hline \multicolumn{2}{|c|}{ Elverişli $\mathrm{P}\left(\mathrm{P}_{2} \mathrm{O}_{5} \mathrm{~kg} \mathrm{da}^{-1}\right)$} & 17.01 & 23.41 \\
\hline \multicolumn{2}{|c|}{ K.D.K. (me $100 \mathrm{~g}^{-1}$ toprak) } & 38.63 & 46.71 \\
\hline \multirow{4}{*}{$\begin{array}{l}\text { Değişebilir katyonlar } \\
\text { (ppm) }\end{array}$} & $\mathrm{Ca}$ & 157.70 & 213.40 \\
\hline & $\mathrm{Mg}$ & 34.16 & 52.70 \\
\hline & $\mathrm{K}$ & 11.6 & 13.14 \\
\hline & $\mathrm{Na}$ & 6.32 & 5.21 \\
\hline \multirow{5}{*}{$\begin{array}{l}\text { Mikro } \\
\text { (ppm) }\end{array}$} & $\mathrm{Fe}$ & 7.24 & 6.94 \\
\hline & $\mathrm{Cu}$ & 1.54 & 1.17 \\
\hline & $\mathrm{Zn}$ & 1.05 & 0.824 \\
\hline & $\mathrm{Mn}$ & 10.28 & 8.76 \\
\hline & $\mathrm{B}$ & 0.26 & 0.35 \\
\hline \multirow{3}{*}{$\begin{array}{l}\text { Tane büyüklük dağıımı, } \\
\%\end{array}$} & Kum & 44.8 & 19.8 \\
\hline & Kil & 27.0 & 21.0 \\
\hline & Silt & 28.2 & 59.2 \\
\hline \multicolumn{2}{|l|}{ Tekstür sınıfı } & TIN & KIL \\
\hline \multicolumn{2}{|l|}{ Toplam tuz (\%) } & 0.017 & 0.012 \\
\hline \multicolumn{2}{|l|}{ Tarla kapasitesi (\%) } & 27.40 & 49.0 \\
\hline \multicolumn{2}{|c|}{ Solma noktası (\%) } & 13.80 & 28.16 \\
\hline \multicolumn{2}{|c|}{ Total bakteri sayısı, cfu g-1 toprak } & $4.5 \times 10^{7}$ & $4.8 \times 10^{7}$ \\
\hline \multicolumn{2}{|c|}{ Total mantar sayısı, spor g ${ }^{-1}$ toprak } & $3.8 \times 10^{5}$ & $4.1 \times 10^{5}$ \\
\hline \multicolumn{2}{|c|}{ Toprak $\mathrm{CO}_{2}$ solunumu, $\mathrm{mgCO}_{2} \mathrm{~m}^{-2} \mathrm{~h}^{-1}$} & 16.73 & 20.90 \\
\hline
\end{tabular}

Deneme alanı toprakları tınlı ve killi bünyeli, kireçli ve hafif alkali olup; organik madde ve yarayışlı fosfor bakımından yetersiz ve tuzluluk problemi mevcut değildir. Topraklar organik madde ve yarayışı fosfor bakımından yetersiz ve tuzluluk problemi mevcut değildir (Çizelge 1). 


\section{Konsantre Deterjan Çözeltilerinin Toprakların Bazı Özellikleri Üzerine Etkileri}

\section{Toprakların reaksiyonu üzerine etkileri}

Hazırlanan 6 farklı deterjanın konsantre çözeltileri Çiftlik ve Daphan Bölgesi saksı topraklarına sulama suyu olarak 30,60 ve 90 günlük periyotlarda uygulanmış ve elde edilen sonuçlara göre; konsantre deterjan çözeltileri uygulamaları toprakların $\mathrm{pH}$ değerlerinde başlangıç $\mathrm{pH}$ değerine göre değişim göstermiştir. İnkübasyon sürelerine bağlı olarak farklı deterjan çözelti uygulamalarının toprak pH değerleri üzerine etkisi önemli farklılık göstermemiştir (Şekil 1).

Çiftlik Bölgesi ve Daphan Bölgesi topraklarına uygulanan 6 farklı toz deterjanın konsantre (Kkon) çözeltileri farklı inkübasyon sürelerinde toprakların ortalama $\mathrm{pH}$ değerlerinde artışa sebep olmuştur. Kontrol toprağına göre Çiftlik topraklarında; en düşük $\mathrm{pH}$ değeri $\mathrm{D}_{6}$ deterjanının 30 günlük inkübasyon süresinde, en yüksek $\mathrm{pH}$ değeri ise $D_{5}$ deterjanının 90 günlük inkübasyon süresinde belirlenmiştir. Daphan Bölgesi topraklarında; en düşük $p H$ değeri $D_{6}$ deterjanının 30 günlük inkübasyon süresinde, en yüksek $\mathrm{pH}$ değeri ise $\mathrm{D}_{2}$ deterjanının 90 günlük inkübasyon süresinde tespit edilmiştir (Şekil 1).

Bazik katyonlar ihtiva eden farklı deterjanların konsantre çözeltileri toprak reaksiyonunda artışlara sebep olmuştur. Topraklara deterjan çözeltisi uygulamalarının toprak $\mathrm{pH}$ ve $E C$ değerlerinde artışa sebep olduğu Pinto ve ark. (2010) tarafından yapılana benzer bir çalışmada da ifade edilmiştir. Genel olarak çamaşır deterjanlarının yüksek alkalin özelliğe sahip olması çamaşır yıkama sularının pH'sının (pH 8 ila 10) yüksek olduğu ifade eden çalışmalar bizim bulduğumuz sonuçları desteklemektedir (ChristovaBoal ve ark. 1996; Eriksson ve ark. 2002).

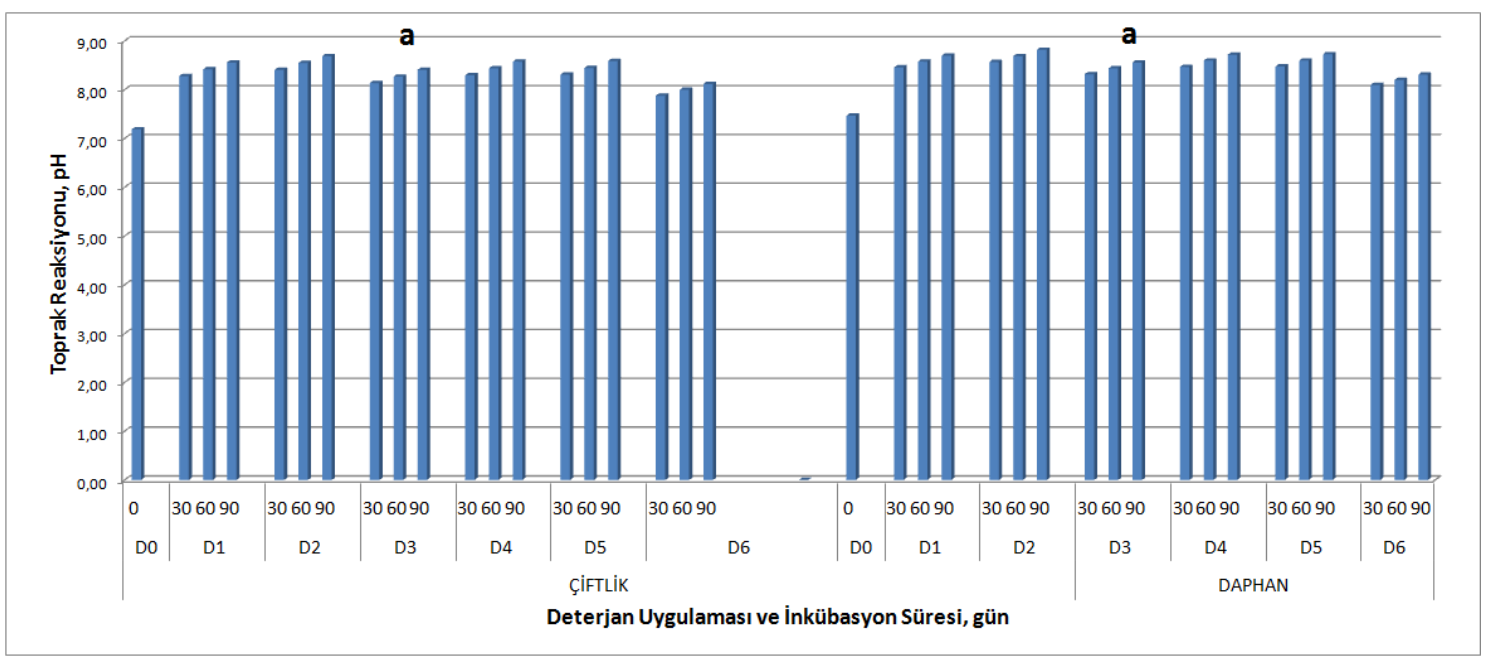

Şekil 1. Topraklara uygulanan konsantre deterjan çözeltilerinin farklı inkübasyon sürelerinde toprak reaksiyonu üzerine etkileri ve varyans analiz sonuçları.

Toprakların bakteri ve mantar popülasyonu üzerine etkileri

Çiftlik ve Daphan bölgesi topraklarına uygulanan konsantre deterjan çözeltileri bakteri ve mantar popülasyonunda kontrol toprağına göre azalışa sebep olmuştur. Farklı inkübasyon sürelerinde farklı deterjan çözelti uygulamalarının toprak bakteri ve mantar popülasyonu üzerine etkisi önemli $(p<0.05)$ farklılıklar göstermiştir (Şekil 2).

Çiftlik Bölgesi topraklarında en düşük bakteri sayısı $D_{3}$ deterjanının 90 günlük inkübasyon süresinde, en yüksek bakteri sayısı ise D6 deterjanının 30 günlük inkübasyon süresinde gözlenmiştir. En düşük mantar sayısı $D_{5}$ deterjanının 90 günlük inkübasyon süresinde, en yüksek mantar sayısı ise $D_{6}$ deterjanının 30 günlük inkübasyon süresinde gözlenmiştir. Daphan Bölgesi topraklarında ise; en düşük bakteri sayısı $D_{5}$ deterjanının 90 günlük inkübasyon süresinde, en yüksek bakteri sayısı ise $D_{6}$ deterjanının 30 günlük inkübasyon süresinde gözlenmiştir. En düşük mantar sayısı $\mathrm{D}_{4}$ deterjanının 90 günlük inkübasyon süresinde, en yüksek mantar sayısı ise $\mathrm{D}_{5}$ deterjanının 30 günlük inkübasyon süresinde gözlenmiştir (Şekil 2). 
Yapılan çalışmada; topraktaki mikroorganizma grupları üzerine en düşük toksik etkinin, en düşük deterjan konsantrasyonunda (\%0.001) gözlendiği, özellikle \%0.1-1 konsantrasyonda mikroorganizma gelişiminin hemen hemen inhibe edildiğini ancak; oligonitrofili bakteri, mikroorganizmaların en dirençli grubu olan toprak mantarlarının daha az etkilendiği ifade edilmektedir (Mandic ve ark. 2006). Deterjan çözeltilerinin suya ve toprağa kontrolsüz olarak boşaltılması, bu ekosistemlerdeki toprak mikroorganizmalarının biyolojik aktivitelerini olumsuz etkilediği ve temel olarak, deterjan konsantrasyonlarının artması veya toprakta birikmesi sonucu mikroorganizmaların sayısının hızlı bir şekilde azatlığını ifade eden çalışmalar (Goncaruka ve Sidorenko 1986; Stojanovic ve ark. 1990) bizim sonuçlarımız ile benzerlik oluşturmaktadır.

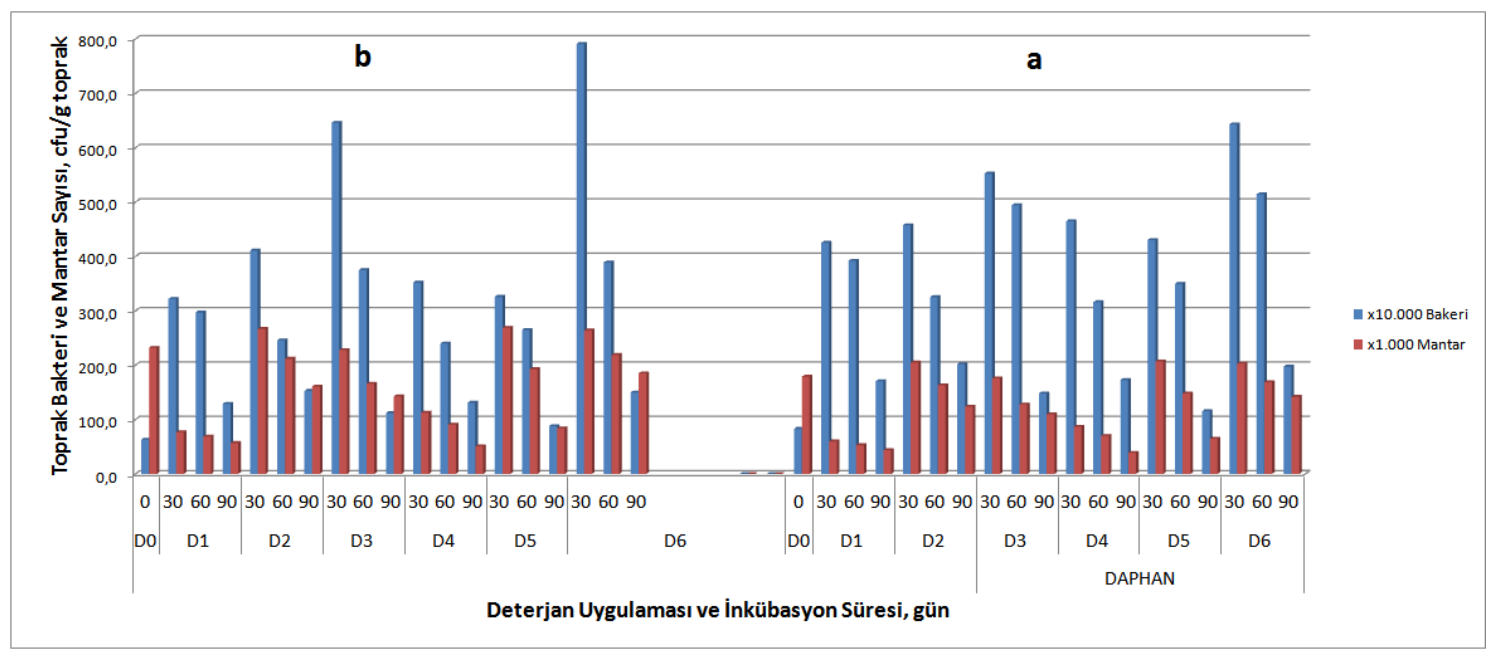

Şekil 2. Topraklara uygulanan deterjan çözeltilerinin farklı inkübasyon sürelerinde toprak bakteri ve mantar popülasyonu üzerine etkileri ve varyans analiz sonuçları.

\section{Toprakların $\mathrm{CO}_{2}$ solunumu üzerine etkileri}

Toprakların $\mathrm{CO}_{2}$ solunum değerleri üzerine, konsantre deterjan çözelti uygulamaları kontrol toprağına göre artışına sebep olmuştur. Farklı inkübasyon sürelerinde deterjan çözelti uygulamaları toprak $\mathrm{CO}_{2}$ değerleri üzerine önemli $(p<0.05)$ farklılıklar göstermiştir (Şekil 3).
Çiftlik Bölgesi topraklarında en düşük $\mathrm{CO}_{2}$ miktarı $D_{5}$ deterjanının 90 günlük inkübasyon süresinde, en yüksek $\mathrm{CO}_{2}$ miktarı ise $\mathrm{D}_{4}$ deterjanının 30 günlük inkübasyon süresinde gözlenmiştir. Daphan Bölgesi topraklarında en düşük $\mathrm{CO}_{2}$ miktarı $\mathrm{D}_{1}$ deterjanının 90 günlük inkübasyon süresinde, en yüksek $\mathrm{CO}_{2}$ miktarı ise $\mathrm{D}_{4}$ deterjanının 30 günlük inkübasyon süresinde gözlenmiştir (Şekil 3).

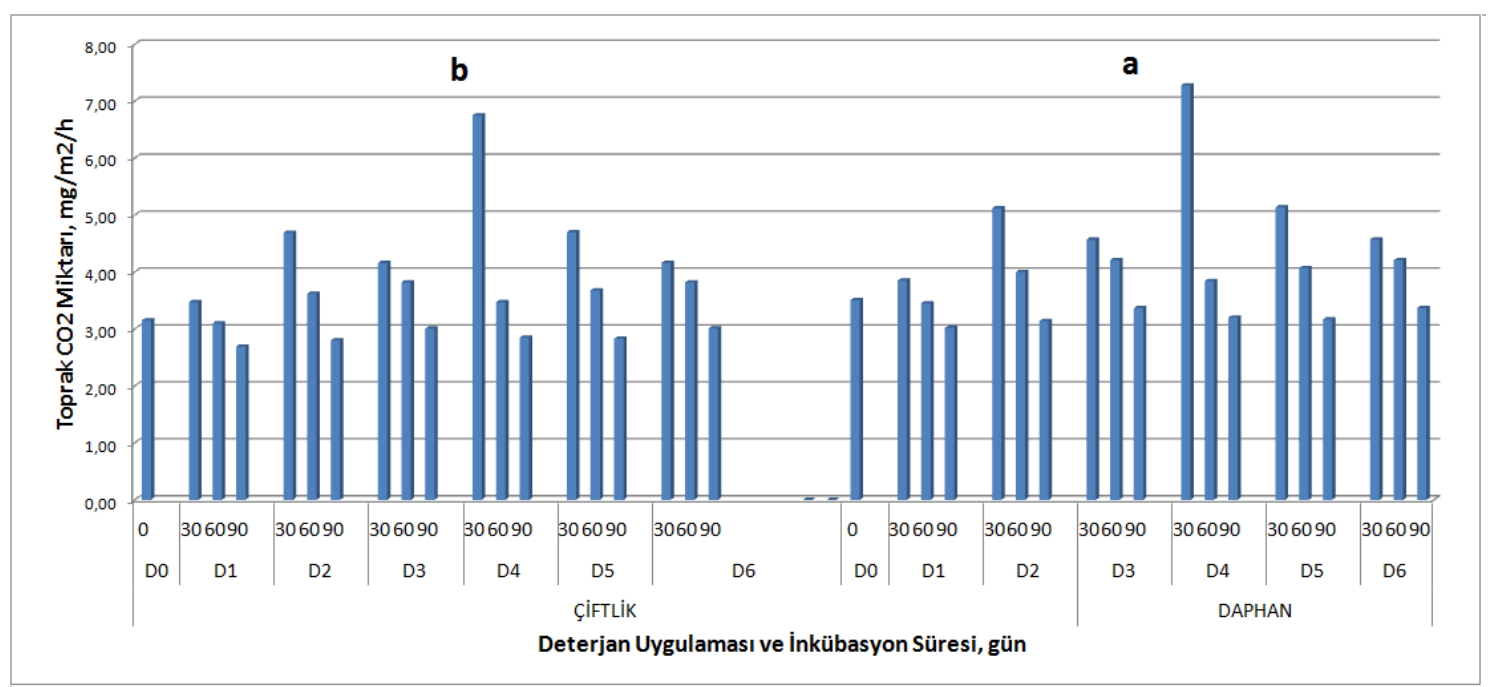

Şekil 3. Topraklara uygulanan deterjan çözeltilerinin farklı inkübasyon sürelerinde toprak $\mathrm{CO}_{2}$ salınımı üzerine etkileri ve varyans analiz sonuçları. 


\section{Toprakların değişebilir $\mathrm{Na}$ içeriği üzerine etkileri}

Toprakların değişebilir Na içerikleri üzerine, konsantre deterjan çözelti uygulamaları kontrol toprağına göre artışına sebep olmuştur. Farklı inkübasyon sürelerinde deterjan çözelti uygulamalarının toprak değişebilir $\mathrm{Na}$ içerikleri üzerine etkisi önemli $(p<0.01)$ farklılıklar göstermiştir (Şekil 4).
Çiftlik Bölgesi topraklarında en düşük değişebilir $\mathrm{Na}$ miktarı $D_{6}$ deterjanının 30 günlük inkübasyon süresinde, en yüksek değişebilir $\mathrm{Na}$ miktarı ise $\mathrm{D}_{2}$ deterjanının 90 günlük inkübasyon süresinde gözlenmiştir. Daphan Bölgesi topraklarında en düşük değişebilir Na miktarı $D_{6}$ deterjanının 30 günlük inkübasyon süresinde, en yüksek değişebilir $\mathrm{Na}$ miktarı ise $\mathrm{D}_{2}$ deterjanının 90 günlük inkübasyon süresinde belirlenmiştir (Şekil 4).

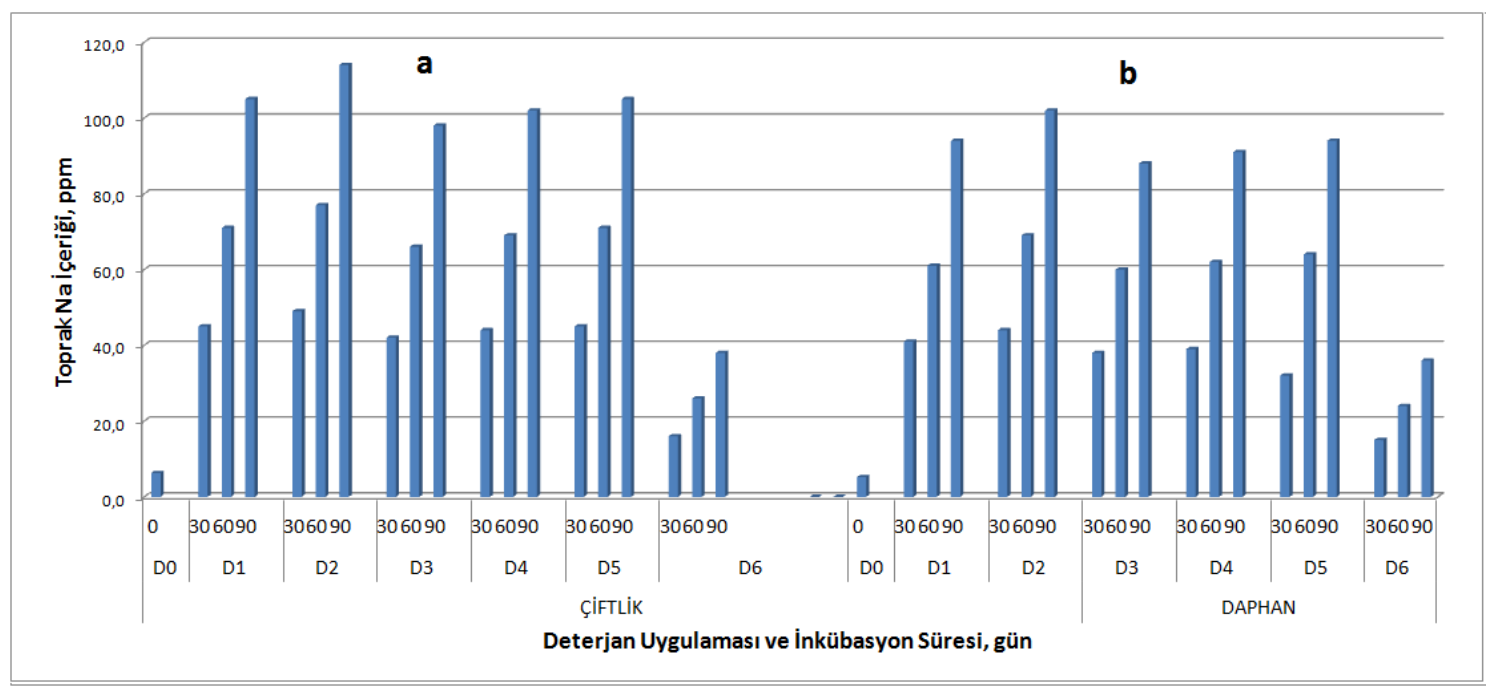

Şekil 4. Topraklara uygulanan deterjan çözeltilerinin farklı inkübasyon sürelerinde toprak değişebilir Na içerikleri üzerine etkileri ve varyans analiz sonuçları.

\section{Toprakların toplam $\mathbf{N}$ ve elverişli $\mathbf{B}$ içeriği üzerine etkileri} Konsantre deterjan çözelti uygulanmaları, toprakların ortalama toplam $\mathrm{N}$ ve elverişli $\mathrm{B}$ içeriklerinde kontrol toprağına göre artışa sebep olmuştur. Farklı inkübasyon sürelerinde deterjan çözelti uygulamalarının toprakların toplam azot değerleri üzerine etkisi $(p<0.05)$ ve elverişli $B$ içerikleri üzerine etkisi önemli $(p<0.01)$ farklılıklar göstermiştir (Şekil 5).

Toprakların Na içerikleri deterjanların Na içeriklerine bağı olarak topraktaki birikim değerleri de farklı olmuştur. İnkübasyon süresindeki artışlar toprakların $\mathrm{Na}$ içeriğini de artırmıştır. Sodyum tuzu bileşikleri, deterjanlarda bulunan diğer kimyasal bileşenlerin kimyasal aktivitelerine yardımcı olan suda çözünürlük özelliklerinin yüksek olması nedeniyle toz deterjanlarda yaygın olarak kullanılmaktadır (Patterson 2000). Sodyum klorür bazen deterjanlarda iyon değiştirici olarak kullanılır (Eriksson ve ark. 2002). Artan sodyum kil parçacıklarını bir arada tutan kuvvetlerin bozulması yoluyla toprak dağııımını ve kil kolloidlerinin ve agregatlarının şişmesini sağlayarak toprak yapısını olumsuz bir şekilde etkileyebilir (Warrence ve ark. 2003). Bu sebeple deterjan çözeltilerinin $\mathrm{Na}$ içeriğinin yüksek olması toprakların da $\mathrm{Na}$ içeriklerinin artmasında önemli bir sebep olmuştur.

Çiftlik ve Daphan Bölgesi topraklarında en düşük toplam $\mathrm{N}$ miktarı $D_{1}$ deterjanının 30 günlük inkübasyon süresinde, en yüksek toplam $\mathrm{N}$ miktarı ise $\mathrm{D}_{4}$ deterjanının 90 günlük inkübasyon süresinde gözlenmiştir. Çiftlik ve Daphan Bölgesi topraklarında en düşük elverişli $B$ miktarı $D_{1}$ deterjanının 30 günlük inkübasyon süresinde, en yüksek elverişli $B$ miktarı ise $D_{6}$ deterjanının 90 günlük inkübasyon süresinde gözlenmiştir (Şekil 5).

Sabunlarda ve deterjanlarda bulunan sodyum perborat çözeltideki B kaynağını oluşturmaktadırlar (Gross ve ark. 2005). Genel olarak B biyolojik bozulmaya (Fox ve ark. 2002) uğramadığı ve bir takım çevresel sorunlara neden olabildiği için deterjanlarda bor kullanımı bazı ülkelerde sınırlıdır (Gross ve ark. 2005) 
Topraklar B içerikleri bakımından bütün bitkiler için sorun teşkil etmeyen az borlu (0.7 ppm'e kadar B içeren), bazı bitkiler için sorun oluşturmayan orta borlu (0.7-1.5 ppm bor), çoğunlukla bitkiler için sorun oluşturan yüksek borlu (1.5- $3.75 \mathrm{ppm}$ ) ve bütün bitkiler için tehlikelidir çok yüksek borlu (3.75 ppm'den fazla B içeren) topraklar
(Özgül 1974) olarak sınıflandırılırlar. Çalışmadan elde edilen sonuçlara göre $D_{6}$ deterjanının yüksek bor içeriğine sahip olması inkübasyon süresinin artışına bağlı olarak bu toprakların B konsantrasyonunun artmasına sebep olmuşlardır.

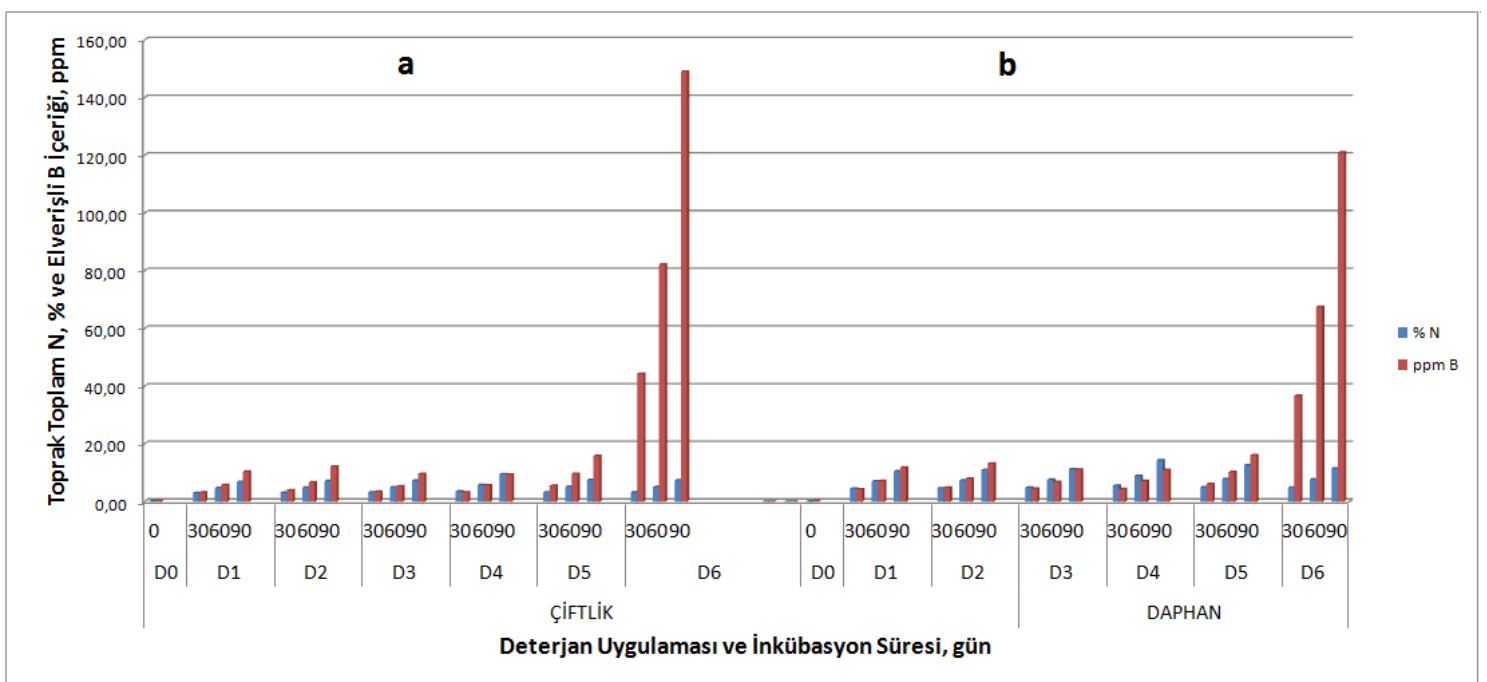

Şekil 5. Topraklara uygulanan deterjan çözeltilerinin farklı inkübasyon sürelerinde toprak toplam $\mathrm{N}$ ve Elverişli B içerikleri üzerine etkileri ve varyans analiz sonuçları.

\section{Toprakların elverişli P içeriği üzerine etkileri}

Konsantre deterjan çözelti uygulamaları toprakların ortalama elverişli $\mathrm{P}_{2} \mathrm{O}_{5}$ içeriklerinde kontrol toprağına göre artışına sebep olmuştur. Farklı inkübasyon sürelerinde deterjan çözelti uygulamalarının toprak elverişli $\mathrm{P}_{2} \mathrm{O}_{5}$ içerikleri üzerine etkisi önemli $(p<0.01)$ farklılıklar göstermiştir (Şekil 6).

Araştırma sonuçları, deterjan çözeltilerinin P içeriklerine ve inkübasyon sürelerinin artışına bağlı olarak topraklarda P miktarların da arttırdığını göstermiştir.

Çiftlik ve Daphan Bölgesi topraklarında en düşük elverişli $\mathrm{P}_{2} \mathrm{O}_{5}$ miktarı $\mathrm{D}_{6}$ deterjanının 30 günlük inkübasyon süresinde, en yüksek elverişli $\mathrm{P}_{2} \mathrm{O}_{5}$ miktarı ise $\mathrm{D}_{3}$ deterjanının 90 günlük inkübasyon süresinde gözlenmiştir (Şekil 6).

Deterjanlar içerisinde bulunan $\mathrm{P}$ miktarının çevresel ve ekonomik gerekçeler açısından sorunlar oluşturması sebebi ile kullanımı azaltılmaktadır (Liu ve ark. 2008). Özellikle deterjanlardaki fosfatlar, sudaki ötrofikasyondan sorumludurlar (Schindler 1974; Lee ve ark. 1978; Smith ve ark. 1999). Sudaki bir önemli sınırlayıcı besin maddesi olan aşırı fosfatlar bakteri ve alg oluşumunu tetikleyebilir ve suya doygun ortamlarda anaerobik koşullara neden olabilirler (Schindler 1974; Smith ve ark. 1999; Yangxin ve ark. 2008). 


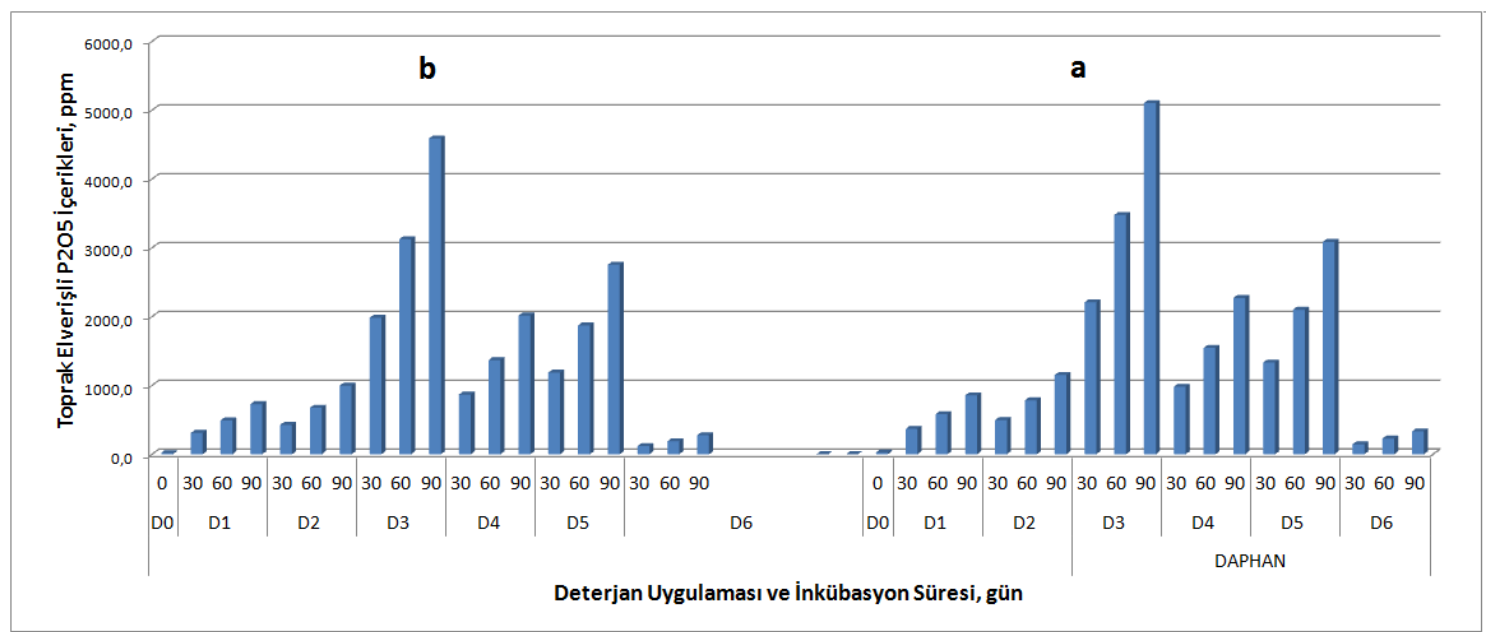

Şekil 6. Topraklara uygulanan farklı konsantre deterjan çözeltilerinin farklı inkübasyon sürelerinde toprak elverişli $\mathrm{P}_{2} \mathrm{O}_{5}$ içerikleri üzerine etkileri ve varyans analiz sonuçları.

\section{SONUÇLAR ve ÖNERILER}

Çiftlik ve Daphan Bölgesi topraklarına uygulanan 6 farklı toz deterjanın konsantre (Kkon) çözelti uygulamaları inkübasyon süresinin artışına bağlı olarak toprakların ortalama reaksiyon $(\mathrm{pH})$ değerlerini artırmıştır. Toprak reaksiyonundaki artış deterjan çeşitlerine ve deterjan çözeltilerinin içeriklerine bağlı olarak değişiklik göstermiştir. Toprak reaksiyonundaki artışlar hafif bünyeli topraklarda daha yüksek oranda gerçekleşmiştir.

Toz deterjanlarının konsantre (Kkon) çözelti uygulamaları inkübasyon süresinin artışına bağlı olarak toprakların ortalama değişebilir $\mathrm{Na}$, toplam $\mathrm{N}$ ve elverişli $\mathrm{P}$ ve $\mathrm{B}$ içerikleri değerlerini artırmıştır.

Toprakların değişebilir $\mathrm{Na}$, toplam $\mathrm{N}$ ve elverişli $\mathrm{P}$ ve $\mathrm{B}$ içerikleri deterjan çeşitlerine ve deterjan çözeltilerinin içeriklerine bağlı olarak değişiklik göstermiştir. Topraklardaki değişebilir $\mathrm{Na}$, toplam $\mathrm{N}$ ve elverişli $\mathrm{P}$ ve $\mathrm{B}$ içeriklerindeki artışlar hafif bünyeli topraklarda daha yüksek oranda gerçekleşmiştir.

Aynı şekilde; Konsantre (Kkon) dozlarda deterjan uygulaması farklı inkübasyon sürelerinde toprakların $\mathrm{CO}_{2}$ salınımı, bakteri ve mantar sayıları azalma göstermiştir. Toprakların $\mathrm{CO}_{2}$ salınımı, bakteri ve mantar sayıları deterjan çeşitlerine ve deterjan çözeltilerinin içeriklerine bağı olarak değişik oranlarda gerçekleşmiştir. Topraklardan $\mathrm{CO}_{2}$ salınımında, bakteri ve mantar sayılarındaki azalma hafif bünyeli topraklarda daha yüksek oranda gerçekleşmiştir.

Mevcut toz deterjanlarının konsantre (Kkon) çözelti uygulamaları inkübasyon süresinin artışına bağı olarak Çiftlik Bölgesi topraklarının bakteri, mantar ve $\mathrm{CO}_{2}$ miktarı üzerine olumsuz etkileri gözlenirken, toprak reaksiyonu, değişebilir $\mathrm{Na}$, toplam $\mathrm{N}$, elverişli $\mathrm{B}$ ve elverişli $\mathrm{P}_{2} \mathrm{O}_{5}$ miktarları üzerinde pozitif etkileri gözlenmiştir.

Aynı çözeltilerin Daphan Bölgesi topraklarının bakteri, mantar ve $\mathrm{CO}_{2}$ miktarı üzerine olumsuz etkileri gözlenirken, toprak reaksiyonu, değişebilir $\mathrm{Na}$, toplam $\mathrm{N}$, elverişli $B$ ve elverişli $\mathrm{P}_{2} \mathrm{O}_{5}$ miktarları üzerinde pozitif etkileri gözlenmiştir.

Yapılan araştırma sonucuna bağlı olarak;

Üretilen deterjan ve türevlerinin doğa kirlenmesinde önemli katkısı olduğu için üretim aşamalarına ve üretim sonrasında bir dizi önlemler alınarak kontrol edilmesi,

Deterjan çözeltilerinin topraklara olumsuz etkilerini azaltmak için sulama suyu kalitesi, toprak geçirgenliği, organik madde içeriği, sulama hızı, yeraltı suyu derinliği ve drenaj özellikleri gibi birtakım faktörleri göz önüne alınması,

Fosfat içermeyen deterjanların üretilerek deterjan türevli fosfatların yasak veya sınırlamalar yoluyla azaltılması, 
Deterjanlarda bor kullanımının bir takım çevresel sorunlara neden olması sebebi ile dikkatli ve sınırlı kullanımının yapılması, ayrıca topraklardan borun uzaklaştırma metotlarının araştırılması,

Deterjan atıklarının suya ve tarım topraklarına kontrollü olarak uygulanması ve biyolojik ekosistemlerin korunması,

Temizlik işlerimizde kullandığımız deterjanların çevre kirlenmesi ve sağlı̆ımı açısından zararlarından korunabilmek için üretimlerinin kontrol altında tutulması,

Sağlık Bakanlığı tarafından sağlığa ve çevre kirlenmesine en az zararlı bileşimlerin saptanıp bu standardın dışında deterjan üretimine izin verilmemesi sağlanmalıdır.

\section{TEŞEKKÜR}

Bu çalışma Yüksek Lisans Tezi olarak Atatürk Üniversitesi Bilimsel Araştırma Projeleri (BAP) kapsamında desteklenmiştir, Proje No: 2015-181.

\section{KAYNAKLAR}

Akgül M (1987) Atatürk Üniversitesi topraklarında pulluk tabanı oluşumu üzerine bir araştırma, Yüksek Lisans Tezi, Atatürk Üniv Fen Bil Enst Erzurum

Akgül M (1992) Daphan Ovası toprakların sınıflandırılması ve haritalanması (Doktora Tezi Yayınlanmamış)

Akgül M, Öztaş T, Canbolat MY (1995) Atatürk Üniversitesi çiftliği topraklarında tekstürel değişimin jeoistatistiksel yöntemlerle belirlenmesi, i. Akalan Toprak ve Çevre Sempozyumu, Cilt I, S: A82A91 Ankara

Al-Hamaiedeh H, Bino M (2010) Effect of treated grey water reuse in irrigation on soil and plants, Desalination 256 (1-3): 115-119

Altınlı IE, Pamir HN, Erentüz C (1963) 1/500000 Ölçekli Jeoloji Haritası, Erzurum Paftası, MTA Enstitüsü Yayınları, Ankara

Anonim (2012) Genel Olarak kimyasal temizlik ürünleri zararları, http://cleanball.blogcu.com/genel-olarak-kimyasal-temizlikurunleri-zararlari/3756750

Atalay i (1978) Erzurum Ovası ve çevresinin jeolojisi ve jeomorfolojisi, Atatürk Üniversitesi Yayınları No:91, Erzurum

Aydın A, Sezen Y (1995) Toprak kimyası laboratuar kitabı, Atatürk Üniversitesi Ziraat Fakültesi Ders Yayınları No:174, Erzurum

Bajpai D, Tyagi VK (2007) Laundry detergents: An overview, Journal of Oleo Science, 56: 327-340

Carson PA, Fairclough CS, Mauduit C, Colsell M (2006) Peroxy bleaches: Part 1 Background and techniques for hazard evaluation, Journal of Hazardous Materials

Christova-Boal D, Eden RE, Mc Farlane S (1996) An investigation into greywater reuse for urban residential properties, Desalination 106: 391-397

Demiralay i (1993) Toprak fiziksel analizleri, Atatürk Üniversitesi Ziraat Fakültesi Yayınları No:143, Erzurum
Devlet Meteoroloji İ̧̧leri Genel Müdürlüğü, (2016) Resmi İstatistikler, https://www.mgm.gov.tr/veridegerlendirme/il-ve-ilceleristatistik.aspx?m=ERZURUM

Dökmeci i (2012) Çevre ve deterjan, http://www.dijimecmua.com/naturelife/1092/index/965843_

Erbay i (2011) Su - Sabun - Deterjan, http://egecikdogalsabun.blogspot.com/p/gida-muhendisi-ismailerbayin-makalesi.html.

Eriksson E, Auffarth K, Henze M, Ledin A (2002) Characteristics of grey wastewater, Urban Water 4: 85-104

Fox KK, Cassani G, Facchi A, Schröder FR, Poelloth C, Holt MS (2002) Measured variety in boron loads reaching European sewage treatment Works, Chemosphere 47: 499-505

Gee GW, Bauder JW (1986) Practicle-size analysis, Methods of soil analysis Part I.Physical and Mineralogical Methods, Second Edition American Society of Agronomy, Soil Sci. Society of AmericaMadison, Visconsin, USA, 383-409

Germida JJ (1993) Cultural methods for soil microorganisms, In:Martin RC, editör, Soil Sampling and Methods of Analysis, Boca Raton, FL, USA: Lewis Publishers, pp 263-275

Goh T, Boon Arnaud RJ St, Mermut AR (1993) Carbonaters, Chapter 20, Soil sampling and methods of analysis, Edited by: Martin R Carter, Canadian Society of Soil Science, Lewis Publishers, Boca Raton, Florida, 177-185

Goncaruka El, Sidorenko SI (1986) Rukovodstvo, Moskva

Gross A, Azulai N, Oron G, Ronen Z, Arnold M, Nejidat A (2005) Environmental impact and health risks associated with greywater irrigation: A case stud, Water Science and Technology 52: 161-169

Hendershot WH, Lalande $H$, Duquette M (1993) Soil reaction and excahngeable acidity, Chapter 16, Soil Sampling and Methods of Analysis, Edited by: Martin R.Carter, Canadian Society of Soil Science, Lewis Publishers, Boca Raton, Florida, 141-145

Islam KR, Weil RR (2000) Land use effect on soil quality in tropical forest ecosystem of Bangladesh, Agriculre, Ecosystems, and Environment, 79: 9-16

Kızıloğlu FT, Bilen S (1997) Toprak mikrobiyolojisi laboratuvar uygulamaları, Atatürk Üniversitesi Ziraat Fakültesi Yayınları No:193, Atatürk Üniversitesi Ziraat Fakültesi, Ofset Tesisleri, Erzurum

Knudsen D, Peterson GA, Pratt PF (1982) Lithium, sodium and potasium, Methods of Soil Analysis Part 2, Chemical and Microbiological Properties Second Edition, American Society of Agronomy, Soil Science Society of America-Madison, Visconsin, USA, 225-245

Kolber E (1990) Detergents, the consumer and the environment, Chemistry and Industry 6: 179-181

Lanyon LE, Heald WR (1982) Magnesium, calcium, strontium and barium, Methods of Soil Analysis Part 2, Chemical and Microbiological Properties, Second Edition, American Society of Agronomy, Soil Science Society of America-Madison, Visconsin, USA, 247-260

Lee GF, Rast W, Jones RA (1978) Eutrophication of water bodies: Insights for an age-old problem, Environmental Science and Technology 12: 900-908

Liu Y, Villalba G, Ayres RU, Schroder H (2008) Global phosphorus flows and environmental impacts from a consumption perspective, Journal of Industrial Ecology 2: 229-247

Malmos H (1990) Enzymes for detergents, Chemistry and Industry 6, 183-186

Mandic D, Djukic SK (2006) Effect of different detergent concentrations on the soil microorganisms number, Acta Agriculturae Serbica, 22: 69-74 
Mc Gill WB, Figueiredo CT (1993) Total nitrogen, Chapter 22, Soil Sampling and Methods of Analysis, Edited by: Martin R.Carter, Canadian Society of Soil Science, Lewis Publishers, Boca Raton, Florida, 201-211

Mercola DR (2012) The Worst Ingredients in Laundry Detergent, http://www.care2.com/greenliving/the-worst-ingredients-inlaundry-detergent.html\#ixzz2ot2iQ0ql

Mertens D (2005) AOAC Official Method 975.03. Metal in Plants and Pet Foods, Official Methods of Analysis, 18th edn. Horwitz, W and GW Latimer, (Eds). Chapter 3, pp 3-4, AOAC-International Suite 500, 481. North Frederick Avenue, Gaitherburg, Maryland 208772417, USA

Olsen SR, Sommers LE (1982) Phosphorus, Methods of Soil Analysis Part 2, Chemical and Microbiological Properties, Second Edition, American Society of Agronomy. Soil Science Society of AmericaMadison, Visconsin, USA, 403-427

Özgül Ş (1974) Tuzluluk ve Sodiklik, Teknik Rehber, Uluslararası Sulama ve Drenaj Komisyonu Türk Milli Komitesi, Yayın No 2 Ankara

Pasinli T (2009) Deterjanlar Çevreyi Nasıl Etkiler? Ekoloji, Sayı:22

Patterson RA (2000) Wastewater quality relationships with reuse options, Proceedings of the 1st World Water Congress of the International Water Association, 3-7 July, Paris, France

Pettersson A, Adamsson M, Dave G (2000) Toxicity and detoxification of Swedish detergents and softner products, Chemosphere 41, 1611-1620

Pickup J (1990) Detergents and the environment: An industry view, Chemistry and Industry 6, 175-177

Pinto U, Maheshwari BL, Grewal HS (2010) Effects of greywater on plant growth, water use and soil properties, Resources, Conservation and Recycle, 54: 429-435
Rhoades JD (1982) Cation exchange capacity, Methods of Soil Analysis Part 2, Chemical and Microbiological Properties, Second Edition American Society of Argon, Soil Science Society of AmerikaMadison, Visconsin, USA, 149-157

Sağlam T (1994) Toprak ve suyun kimyasal analiz yöntemleri, Trakya Üniversitesi, Tekirdağ Ziraat Fakültesi Yayınları, No:189

Schindler DW (1974) Eutrophication and recovery in experimental lakes: Implications for lake management, Science 184, 897-899

Smith VH, Tilman GD, Necola JC (1999) Eutrophication: Impacts of excess nutrients inputs on freshwater, marine and terrestrial ecosystems, Environmental Pollution 100 179-196

Soil Survey Staff (1999) Soil Taxonomy a Basic System of Soil Classification for Making and Interpreting Soil Surveys 2 nd ed. US Dept. Agric. Soil Conservation Service Washington

Stojanovic J, Veličković D, Soluić-Sukdolak S, Bjelanović D (1990) Mikrobiologija, 27(1) 41

Tiessen H, Moir JO (1993) Total organic carbon, Chapter 21, Soil Sampling and Methods of Analysis, Edited by: Martin RC, Canadian Society of Soil Science, Lewis Publishers, Boca Raton, Florida, 187199

Warrence NJ, Pearson KE, Bauder JW (2003) The Basics of Salinity and Sodicity Effects on Soil Physical Properties, Land Resources and Environmental Sciences Department, Montana State University, Bozeman, $29 \mathrm{pp}$

Yangxin YU, Jin Z, Bayly AE (2008) Development of surfactants and builders in detergent formulations, Chinese Journal of Chemical Engineering 16, 517-527

Yıldız N, Bircan H (1991) Araştırma ve deneme metotları, Atatürk Üniversitesi Yayınları, No:697, Ziraat Fakültesi Yayınları, No:305, Ders Kitapları Serisi No:57, Erzurum 